\title{
The Ideological and Spiritual Transformation of Malcolm X
}

\section{Trevin Jones ${ }^{1}$}

Published online: 18 July 2020

(C) The Author(s) 2020

\begin{abstract}
This paper explores the nexus between incarceration, spirituality, and self-discovery through the literary lens of The Autobiography of Malcolm X.
\end{abstract}

Keywords Note: This data is mandatory. Please provide.Spirituality Identity $\cdot$ Masculinity · Muslim · Incarceration · Nation of Islam

\section{The Evolving Ideology of Malcolm X}

For many African American males inside and outside of prison, Malcolm X embodies the true meaning of manhood, spirituality, and leadership. He personifies the rebel and the reformed, the unsympathetic and passionate, and the incorrigible and scholarly. Malcolm X's life was one of complexity due to many changes, internal and external, that impacted his evolution as a man as well as his broad influence on African American culture. Some scholars argue that Malcom X inspired a generation of African American men while other misguided souls believe his lasting legacy is one of racial polarization. Whether people revere Malcolm as someone who wanted to uplift his race or suspect him to be a figure who widened the racial divide through his unrestrained critique of the American social order, it is safe to say that even in death, his legacy is still evolving. His story fascinates young readers and continues to inspire prison inmates who see Malcolm's life as a reflection of their own. This article examines Malcolm X's spiritual evolution as a former prisoner, Nation of Islam minister, and human rights activist. This work does not explore The Autobiography of Malcolm X from a sentimental gaze but as an avenue to understand many of the deep-seated issues that continue to plague our nation, such as race, incarceration, manhood, and the possibility of conversion behind bars. In addition, I argue that Malcolm X's spiritual

Trevin Jones

jonescovenant@yahoo.com

1 Department of English, St. Louis Community College, St. Louis, MO 63122, USA 
journey and search for ideological soundness remained in a state of flux even at the time of his assassination.

Moreover, people continue to be intrigued by the mystique of Malcolm X, especially because his life was snuffed out before his potential could be actualized. As a result, scholars, spectators, and skeptics are still constructing Malcolm's life story from his interviews, speeches, and time spent with author Alex Haley. One can argue that while Haley may have written a first account of Malcolm X's oral history, there still remains an element of mythology to behind Haley's account, as Malcolm died before his narrative was finished. Shirley K. Rose suggests, "All autobiographical writing contains two distinct literary myths: literacy as a means for achieving individual autonomy and literacy as means of social participation" (Rose 1987, 3). These literary myths are evident in Malcolm X's autobiography because Alex Haley superimposes his language onto Malcolm's words and manipulates how the world at large still views Malcolm's multifaceted life. One can argue that Haley may have reconstituted some of Malcolm's narrative accounts to give his story national and global appeal. Nonetheless, Nell Painter argues "Even when the autobiography is not a collaboration, the narrator passes over much in silence and highlights certain themes that become salient ... [to] what the narrator concludes she or he has become" (Painter 1993, 433). And at the root of all storytelling is the author's ability to transcend literary, cultural, and political boundaries. While scholars continue to debate the validity of Haley's interpretation, Malcolm's life is still considered a great American story because the narrative intertwines three distinct literary tropes: literacy, the self-made man, and the conversion experience. Nevertheless, the centrality of this research is not an examination of authorship, but an exploration into Malcolm's life, a controversial American figure, whose life continues to bring attention to incarceration, recidivism, and the probability of transformation in the lives of former convicts.

Malcolm X was born Malcolm Little in Omaha, Nebraska, in the middle of the roaring twenties at the height of Jim Crow laws and racial segregation. To combat the onslaught of state-sanctioned terrorism against African Americans, families such as the Littles formed very close bonds with local churches and other religious affiliations. As a young boy, Malcolm witnessed his dad preach fiery sermons in Baptist churches. In addition to preaching, his father also made time to spread the doctrine of Marcus Garvey, the founder of the Universal Negro Improvement Association, who encouraged African Americans to, among other things, return to Africa. According to Malcolm X, "The teachings of Marcus Garvey stressed becoming independent of the white man" (Alex Haley 1965, 5). Garvey's philosophy certainly had a profound effect on young Malcolm, as shown by his later choice of a similar path and doctrine that promoted Black solidarity and racial pride. While a large majority of African Americans believed that a higher being would eventually relieve them from their pain and suffering on earth, Malcolm had a hard time placing his confidence in religion or in a supreme being. He states in his autobiography, "I couldn't believe in the Christian concept of Jesus as someone divine" (Haley 1965, 7). Although the text does not state this explicitly, one can infer the possibility that the sudden death of his father and his mother's mental breakdown thereafter contributed to Malcolm's distrust of religion.

While his father exited his life in a literal sense, his mother departed both physically and mentally. Malcolm X's father's death was considered by many in the African American community an unsolved homicide because his body was found severed on 
streetcar tracks. Consumed with grief and unable to care for her family, Malcolm X's mother collapsed emotionally from the anguish and the enormity of having to care for her seven children. She was eventually placed in a mental institution. These two unfathomable losses for Malcolm X are the first in a series of incidents that served as turning points in his life. At such a young age, Malcolm X experienced what most adults dread, yet also understand is imminent. He suffered the literal death of his father at the age of six and the (figurative) passing of his mother at the age of twelve.

The absence of his mother and father left him vulnerable to the lure of the streets and mischievous behavior. As a result, Malcolm X spent time in a foster home and later a reform school. On the way to reform school, a male welfare worker expressed to Malcolm the true meaning of the word reform, which proved to be a foreshadowing to Malcolm's mission in life. In the autobiography, the welfare worker Mr. Maynard Allen asserts, "The word reform means to change and to become better" (Haley 1965, 31). Malcolm was about to undergo a series of changes in a new home, school, and town. One incident in particular that served to remind Malcolm of his place or position in society occurred in the eighth grade, when his Caucasian teacher told him to abandon any dreams of becoming a lawyer. His teacher insisted, "A lawyer is no realistic goal for a nigger" (Haley 1965, 43). These words spoken by Malcolm's teacher devastated Malcolm and caused him to question the importance of an education. Theologian Ryan LaMothe contends, "No matter how bright or gifted Malcolm was, he now knew that all that was left to him was the lowest sphere of economic and cultural life" (LaMothe 2009, 531). The world that his white classmates had privy to by virtue of their race was not available to Malcolm. He recalls this pivotal time as an adolescent when learning became no longer a priority. Malcolm states, "It was then that I began to change inside" (Haley 1965, 44). His desire to learn and to cooperate with those around him was replaced by disappointment that weighed heavy on his mind. This incident caused Malcolm to become even more disillusioned with church and God. Malcolm may have wrestled internally with the following question: How could a loving God allow one race of people to thrive and another race of people to go through life under the cloak of racism and segregation? LaMothe argues, "Malcolm X's withdrawal from and rebellion against the white world and its concomitant expectations of African American submission included his rejection of Christianity" (LaMothe 2009, 531). As a result, Malcolm gave his full attention to the world outside of the classroom, where he gained acceptance and access to life on the streets in Harlem.

Without a father or mother to affirm his humanity and identity, Malcolm gained approval from peers who were only interested in acts of deception and corruption. For instance, one lesson he learned early after his arrival in Boston to live with his half-sister Ella was that far too many people lead fraudulent lives, and everything in the world is a hustle (Haley 1965). Malcolm thrived in the hustler lifestyle, pedaling narcotics, robbing homes, and engaging in prostitution. Archie Epps claims, "He lived up to his nickname-the tough urbane, devil-like Detroit Red" (Epps 1993, 64). While Malcolm was far from the attorney, he once dreamed of becoming, he was gaining notoriety fast between the streets of Boston and Harlem in 1943. (the writer needs to introduce to the reader when Malcolm found himself in Harlem). Like most young people in their teens, he lived with the notion of invincibility. His foreboding sense of indestructability heightened every time he escaped being caught or outwitted his peers on the streets. In Malcolm's autobiography, he recalls this period in his life as a very empty existence. He states, "Through all this time in my life, I really was dead, 
mentally dead" (Haley 1965, 145). Malcolm's eventual arrest in 1946 for burglary awakened him to the severity of his crime and to the irony of finally being out-hustled.

Sitting inside a jail cell brought Malcolm to face to face with the hopelessness and depravity that was far more sinister than the life he knew as a criminal on the streets. He notes, "Behind bars, a man never reforms" (Haley 1965, 176). Malcolm believed locking men away in cages only intensified their propensity for lawless acts because he too took part in illegal activities for a time while incarcerated. Also, his disdain for white people increased, because in his mind, they were the ones that destroyed his family and life: "The white people who kept calling my mother crazy . . . the white people to the Kalamazoo asylum . . . the white judge and others who had split up the children ...." (Haley 1965, 184). Malcolm's internal anger also manifested itself in the way he viewed himself as well. For instance, there was a period of his incarceration where fellow inmates referred to Malcolm as Satan, due to his rejection of anything or anyone spiritual in nature. However, his perception of himself and others changed once he submitted his life to Allah.

While Malcolm was not quite twenty-one and facing a lengthy prison sentence, his life shifted once again when he was introduced to Allah and the Nation of Islam (NOI) by his brother Reginald, who visited Malcolm in prison. Through their lengthy conversation about God (Allah) and a subsequent letter from his brother Philibert, after months of soul-searching, Malcolm decided to adopt their Islamic faith. Malcolm's brothers had aligned their philosophical beliefs with the prophet Elijah Muhammad, who created his own sect of Islam based partly on myths of the African American race and bits and pieces of Orthodox Islam as practiced in Middle East countries.

This was not an easy transition for Malcolm because his former life was entrenched in his thinking and actions. However, over a period of learning more about the Nation of Islam (NOI) and Allah, Malcolm was persuaded to adopt this new belief system that elevated African Americans, instead of reducing them to lowest level of existence. Malcolm X notes, "Christian religion . . . taught the 'Negro' that black was a curse [and] it taught him to hate everything black, including himself' (Haley 1965, 188). And for Malcolm, reading and studying about Africans and African Americans in the context of the NOI affirmed his humanity. Malcolm paralleled his spiritual conversion to that of the biblical figure Paul on the road to Damascus: "I do not now, and I did not then, liken myself to Paul . . . But I do understand his experience" (Haley 1965, 189). This statement is somewhat ironic in that Malcolm would compare his spiritual awakening to that of a Christian prophet considering he vehemently rejects Christianity throughout his narrative. One can also argue that this comparison is a foreshadowing of Malcolm's lifelong search for truth as well as an indication of the internal warring with which he wrestled until his death. Nevertheless, this revelation for Malcolm would now begin to inform his thoughts and actions inside of prison as well as how he perceived others. A pivotal part of Malcolm's salvation experience or surrendering his life to a higher power was his willingness to begin writing letters to Elijah Muhammad and family members to gain a greater understanding of the NOI. This is not surprising because Malcolm was a student of life, and his classroom was now a jail cell instead of the streets of Harlem. Nonetheless, Malcolm was arrested in Boston. In his autobiography, he reflects on the use of a dictionary as the teaching tool that liberated him to freely express himself. Malcolm referred to it as his homemade education. He notes, "Between Mr. Muhammad's teachings, my correspondence, my visitors . . . and my 
reading of books, months passed without my even thinking about being imprisoned ... In fact, up to then, I never had been so truly free in my life" (Haley 1965, 199). This moment in text illustrates not only Malcolm's mental awakening but also the spiritual stirring to know Allah.

Furthermore, the most difficult aspect of submitting to Allah for Malcolm was learning to pray. This meant becoming completely vulnerable and admitting that he needed help from a higher power if he was going to make it through his prison experience. Malcolm contends, "I had to force myself to bend my knees and waves of shame and embarrassment would force me back up . . . For evil to bend its knees, admitting its guilt, to implore the forgiveness of God was the hardest thing in the world ... Again, again, I would force myself back down into the praying-to-Allah posture" (Haley 1965, 197). This act of submission by Malcolm helped him to understand that his life consisted of not just the experiences of his past, but that there was also a future awaiting his rise from obscurity. In addition, as Malcolm continued to grow in his faith and understanding of the NOI, the more he wanted to learn and apply the doctrine to his life.

Elijah Muhammad's brand of Islam was based on an individual by the name of W.D. Fard, who was seminal to the movement in the 1930s. Fard reportedly knocked on the doors of African American families and proclaimed that their true religious identity was Islam. Religious historian Edward Curtis contends, "Fard stayed in Detroit only a little while before disappearing from the city, but his movement would have an impact on the entire country" (Curtis 2006, 2). Elijah Poole, who embraced Fard's brand of Islam, changed his name to Elijah Muhammad and eventually began to follow the earlier teachings of Fard. Curtis points out, "Elijah Muhammad's movement would cement itself in American historical memory as a black nationalist organization committed to racial separation and ethnic pride" (Curtis 2006). Muhammad began proselytizing in the same geographical region of Detroit where W.D. Fard mysteriously vanished; however, Muhammad's separatist message soon spread to other regions of the USA and even abroad. African Americans were drawn to Muhammad's message of racial solidarity because it affirmed their humanity, in time of extreme social and racial oppression. This message was not only preached in the ghettos and urban spaces of America but also spread to prisons as a theology of liberation for the African American male. The NOI reached many Black males in prison because the organization addressed issues of racism and poverty in Black communities, the breakdown of the Black family, rising rates of prisoners of color, and a lack of spiritual guidance. These issues were pertinent to both incarcerated and free Blacks, thus making Muhammad's message of liberation viable to hopeful new converts and intriguing to those somewhat skeptical.

This new belief system set Malcolm on a path toward self-actualization. He was drawn to the NOI along with many other African American male inmates because this religious organization placed a heavy emphasis on Black identity and manhood. Sociologist Magnus O. Bassey suggests, "Islam, according to Malcolm, [meant] freedom, justice, and equality" (Bassey 1999, 50). Also, Islam offered African Americans a position of authority in the creation story, whereas Christianity reduced them to a cursed existence. Bassey further contends, "Christianity had brainwashed African Americans and left them mentally, morally and spiritually dead" (Bassey 1999, 50). In addition, Christianity encouraged its followers to seek their resolve and rest from life's challenges in the afterlife. Bassey also insists, "Malcolm recognized that Christianity misdirected black rage away from white racism and toward another world of heaven 
and sentimental romance" (Bassey 1999). One can reason that prison inmates are more concerned with addressing their current needs and frustrations than with looking to a heaven that may or may not exist. The NOI was able to capitalize on the emotional vulnerability of inmates by promising them a salvation that addressed issues of incarceration, poverty, family, and spirituality. In doing so, Muhammad was able to appeal to the prisoner's sense of loss of self as well as his culture. Malcolm and many other inmates were imprisoned physically and emotionally by what they perceived to be an all-white judicial system with little to no empathy for the Black man. Muhammad knew many of the men he targeted in prison to convert were from impoverished backgrounds and the victims of a racist judicial system, so he took advantage of their vulnerable emotional state and lured many of them to the NOI by demonizing the white race.

One of Malcolm's first letters from Muhammad underscores the plight of the Black prisoner from his vantage point. Muhammad wrote, "The black prisoner symbolized white society's crime of keeping black men oppressed and deprived and ignorant, and unable to get decent jobs, turning them into criminals" (Haley 1965, 195). While Muhammad's letters and methods for recruiting men in prison were divisive, he was able to shift the focus of the prisoner's responsibility back to the problem of race in America. Zoe Colley contends, "The influence of the imprisoned Muslims stretched across the prison walls to help shape the NOI's critique of white privilege and its ideological appeal within ghettos" (Colley 2014, 396). The NOI's doctrine went to great lengths to parallel the existence of Black prisoners to free Blacks living under an oppressive and racist regime.

In addition, Muhammad promised his new converts if they prayed to Allah, a change in their lives would occur. Muhammad's Islam was predicated on the following core values: uplift of the Black race, manhood, and moral transformation. Magnus Bassey suggests, "By becoming a Muslim, the African American becomes a man . . . [and] his lost identity is rediscovered, his never-experienced dignity dawns and he enters life" (Bassey 1999, 53). The promise of manhood or the affirming of an inmate's manhood is what caused the NOI to appeal to so many convicts who lived at the lowest level of existence inside a jail cell and who were also told by the Christian religion that their race was cursed. Anna Hartwell argues, "The Nation offered a nexus of identifications that seemingly existed outside US structures of oppression that nurtured the devastating conjunction of racism and urban poverty" (Hartwell 2008, 209). One of the primary goals of the NOI was to empower African American males by providing them with opportunities for personal growth. Furthermore, Muhammad drew from his own imprisonment in the 1940s for refusing to register for the World War II draft (Colley 2014). Muhammad made sure he appealed to the prisoner's deepest need for human connection and support. Black inmates who felt demoralized and unable to survive emotionally under oppressive penal institutions gravitated toward the NOI because the organization validated their humanity. Colley further asserts, "For African American prisoners, the crucial element of this philosophy was the promise of redemption and hope for the future" (Colley 2014, 402). The NOI did not completely ignore Black criminality; however, the organization chose to place a greater emphasis on the goodness they believed every prisoner was capable of demonstrating.

Also, Muhammad and his followers understood the problem of recidivism that was all too common among inmates, so they worked very hard to present a religious philosophy that addressed every aspect of man's existence. NOI members were 
instructed to adhere to moral decency, respect authority, work hard, live frugally, avoid certain foods, and abstain from alcohol and drugs. Moreover, the NOI also called for political, economic, and social separation from White America (Colley 2014). This separation drew Malcolm, as well as other Black inmates who were intrigued by a religion that refuted societal claims that they were inferior to other races and destined to live as second-class citizens all their lives. Anna Hartwell suggests, "The Nation offered a vehicle through which US blacks might shake off the post-slavery legacy of endemic racism - racism that some brands of Christianity had so enthusiastically justified - by opposing, rather than attempting to assimilate with, dominant notions of Americanness" (Hartwell 2008, 210).

As Malcolm and other inmates accepted the religious ideology espoused by the NOI, many prison officials believed the organization was fashioned to create antagonistic relationships between white prison guards and Black inmates. The fears or distress of prison guards over this religion that captured the minds and hearts of Black inmates through sermons of empowerment and pride in the Black race troubled prison officials to the point that some penal sites forbade inmates to practice Islam. As the NOI's membership in prisons increased, so did the resistance from prison officials, which resulted in Black protest movements in prisons during the late 1950s. Sociologist James B. Jacobs argues, "Prison officials saw in the Muslims not only a threat to prison authority but also a broader revolutionary challenge to American society" (Jacobs 1979, 6). Prison inmates protested against personal, social, and religious injustices. Many of the same injustices that catalyzed racial and social movements outside of prison mirrored the movements that were then taking place inside American prisons.

Moreover, as Black Muslim inmates continued to protest for their rights to practice their beliefs and to proselytize, prison officials persisted in their efforts to hinder them. Prison administrators believed racial hatred was at the core of Black Muslim ideology, which resulted in anarchy. Contrary to the thoughts and feelings of prison officials, Black Muslims claimed white prison officials routinely continued the oppression of American Blacks (Jacobs 1979). What made Black Muslims such a force inside of prisons was that they challenged the caste system, defied penal policies, and initiated litigation. As a result of their willingness to fight for religious and social freedom behind bars, many inmates were politicized in prison in the late 1950s and 1960s. This politicization also stemmed from civil rights groups that did not share all the values of Black Muslims but still recognized the importance of fighting injustice in all areas of society. As Malcolm experienced what he believed to be the sting of injustice, he also went through a spiritual transformation that helped him to see the plight of Black prisoners and Black men in general from a new perspective.

Once he accepted Allah as his God, his mission shifted to sharing the liberating truths of The Nation of Islam with other inmates. Upon his release from prison in 1952, Malcolm immersed himself in the teaching of Muhammad's and the work of the NOI. A year later, he was appointed by Muhammad as Detroit Temple Number One's Assistant Minister (Haley 1965). This appointment allowed Malcolm X to spread the message of Black pride and racial uplift on a fulltime basis. This was yet another pivotal moment in Malcolm's journey because he abandoned a former life on the streets and embraced a spiritual charge to transform himself and his community.

In doing so, he also further distanced himself from the white race and Christianity because, from his vantage point, they both represented oppression. Malcolm's early 
messages to Black Muslims and bystanders were reminiscent of those of his father Earl Little, who also preached a controversial religious and political ideology. Anna Hartwell argues, "The Nation's appropriation of Garveyism - as well as other sources of 19th century as well as 20th century black nationalism - thus hung onto its central symbols while displacing the Christian account of divine authority" (Hartwell 2008). Malcolm believed that Islam was a special religion for African American males, who in his opinion were misguided and conditioned to view themselves as inferior beings through the eyes of the white race. One can argue that Malcolm's rejection of the white cultural-political ethos and religion signified an attempt to find a Black political (and, more latently, religious) subjectivity that would support his self-worth and agency (LaMothe 2009). This was evident in Malcolm's desire as a teenager and young adult to fully fit into the Black urban spaces of Harlem and Boston, where Black subjectivity was affirmed and celebrated. In these spaces, Malcolm absorbed the Black ethos with its idioms and values and its rich stories and rituals though this did not include the Black Christian ethos (LaMothe 2009). From his perspective, Christian teachings and practices hampered the advancement of Blacks whereas Islam promoted Black empowerment and self-reliance.

Under the tutelage of Muhammad, Malcolm immersed himself in a new way of thinking and living as one of the organization's ministers. In addition, his apprenticeship with Muhammad stirred within Malcolm a reverence that was far greater than any feelings he had ever experienced for another human being. As a result of such a great adoration, Malcolm worked very hard to prove his loyalty to Muhammad as well as his devotion to Allah. Everything Malcolm learned through the reading of the Quran and his time with Muhammad, he shared with parishioners and potential converts on the streets of Detroit and in other cities.

In 1959, a nationally televised documentary The Hate That Hate Produced gave Americans their first intimate view of the NOI and its philosophical teachings. Before the documentary, the NOI existed in obscurity from a large portion of the American public. The documentary brought more notoriety to the NOI as well as critics who believed the organization was encouraging hatred toward people who were not of African descent. Edward Curtis claims, "The [expose] on the NOI was generally negative, criticizing the movement as an anti-American or black supremacist group" (Curtis 2006, 4). The undesirable portrayal of the NOI caused many national leaders, Black, and white, to condemn the organization for its separatist ideology. According to Manning Marable, "Malcolm himself thought the show had demonized the Nation, and likened its impact to what happened back in 1938 when Orson Wells frightened America with a radio program describing, as though it was happening, an invasion by men from Mars" (Manning 2011, 162). While detractors attacked the Nation for its controversial beliefs and practices, Malcolm remained steadfast to his convictions and loyalty to the NOI's mission. He continued to represent the Nation even though some members within the organization began to view his charismatic approach and motives as self-serving.

Malcolm placed a great emphasis on illustrating the teachings of Elijah Muhammad's version of Islam. Muhammad always explained at length the atrocities of slavery in building his case that all white men are inherently evil and are devils. Malcolm used this same approach with a style and rhetoric similar to Western tent revival preachers except that he admonished listeners to abandon a Christianity he 
believed condoned the enslavement of the Black race and to adopt a religion that promised true freedom. For example, in a speech entitled "Black Man's History" in 1962 at New York's Mosque \#7, Malcom spoke at length on the importance of African Americans learning their history if they were to successfully overcome the mental and societal assault on their psyche from being viewed as inferior and as second-class citizens. In addition, he argued that the Bible needed to be recovered from the mythic overlays of (white) Christianity in order for its historical veracity to be displayed (Terrill 2001, 30). His objective was to declare that Christian teachings were shrouded in mythology for the purpose of masking the truth of liberation. In doing so, Malcolm filled the role of the prophet to cure the defective vision of the people by debunking and stripping away insidious mythology that renders people blind (Terrill 2001). Malcolm spoke from a prophetic discourse to provoke both a response and action from his audience.

This type of visionary speech is what rhetoricians refer to as jeremiad or apocalyptic rhetoric, terms used to characterize African American protest speech. The first type of discourse examines the following: a consideration of the freedom America promises, a detailed criticism of America's failure to fulfill its promise, and a prophecy that America will eventually achieve its promised greatness (Terrill 2001). Dr. Martin Luther King Jr.'s speech "I Have a Dream" is an example of this type of rhetoric. Also, jeremiad prophecy is more inclusive than exclusive while apocalyptic prophecy declares that the ultimate fulfillment of America's promise will be in a battle between good and evil. This is evident in Confessions by Nat Turner, where he uses apocalyptic rhetoric to rouse listeners to revolutionary action. Robert Terrill suggests, "Characteristic of such texts is an ambivalent role for human agency, for while the fate of the world is not in human hands, this rhetoric does generally advocate some form of human action" (Terrill 2001, 28). Malcolm sought to stir listeners as well to move them past complacency to engagement.

For instance, in his "Declaration of Independence," a statement of freedom from the NOI, Malcolm asserts, "We should be peaceful, law-abiding-but the time has come for the American Negro to fight back with self-defense whenever and wherever he is being unjustly and unlawfully attacked" (Harper 1971, 395). One can argue that by Malcolm suggesting that African Americans, more specifically males, use firearms to fight racial injustices; he is helping to affirm Black manhood. Moreover, men with guns was a symbol of manliness dating back to the old South when white males engaged in military combat as evidence of their courage. Historians Craig Thompson Friend and Lorri Glover suggest, "In the South, no other act more conclusively demonstrated an individual's masculinity than his prowess on the battlefield" (Friend and Glover 2004, 10). A century after the Civil War, Malcolm rallied African American males to engage in the ongoing struggle for human rights and to stand up and be men. Malcolm's extreme rhetoric provoked many in the African American community to defend themselves if necessary while others chose to engage in nonviolent protests. Maria Josefina Saldana-Portillo argues, "Through his words, acts, gestures, and desire, Malcolm X performs the coherence, 'the organizing principle of identity of cause' of the tropic American subject" (Saldana-Portillo 1997, 304). Malcolm is no longer speaking or acting from a space of obscurity, but he has reclaimed his position as a man and inspired other Black males to do so as well.

Regardless of how Malcolm's contentious rhetoric was received by hearers, his words continued to resonate with listeners looking for practical ways to address 
oppression. Moreover, a lot of people who attended Malcolm's meetings could relate very well to his discussions on the economically and socially disadvantaged because many of them were from impoverished backgrounds or Northern ghettos or were poor or poorly educated or a combination of all the aforementioned (Terrill 2001). In Malcolm's reiteration of the speech "Black Man's History," the Black race triumphs in the end. However, this did not mean the struggle for equality and civil rights would suddenly disappear.

In addition, whether Blacks listening to Malcolm fully ascribed to his theological doctrine of Islam, mentioning slavery was his way of appealing to his audience's emotions to get them to reflect on past and current racial acts of violence. "The dramatization of slavery never failed intensely to arouse Negroes . . . and once I had them fired up with slavery, I would shift the scene to themselves" (Haley 1965, 245). He seized the opportunity to create a narrative that elevated Blacks to a place of social and historical significance. Malcolm accomplished this by combining what he learned from Muhammad with his own life experiences and his discoveries about American slavery and the civilizations of Africa (Condit and Lucaites 1993, 295). Furthermore, using a historical framework in his speeches, Malcolm also spoke out against modernday injustices, such as police brutality and economic and political disparities in the Black community.

Malcolm joined the conversation on Black nationalism and encouraged Blacks to take back their communities through social and political involvement. In doing so, he transferred control of Black politics, economics, and morality from Allah and white America to a reconstituted community of socially and economically self-dependent Blacks (Condit and Lucaites 1993). The NOI as an organization did not typically engage in political and social conversations in public forums; however, Malcolm catapulted the NOI onto the national stage through his controversial rhetoric and approach to social activism. Historian Moshik Temkin argues, "Malcolm X knew full well how important the civil rights movement was to many American blacks, but this to him, was a source of agitation: he saw these blacks as hoodwinked and wanted to bring them around to his view" (Temkin 2012, 275). In addition, Malcolm believed that Dr. Martin Luther King, Jr. and others who advocated for equality alongside him approached civil rights from a one-sided perspective. Temkin notes, "It signified a critical difference in how one viewed American blacks: whereas King and the rest of the civil rights mainstream saw American blacks first and foremost as U.S. citizens, deserving full rights and equality as such, Malcolm spoke of 'Afro-Americans,' by which he meant all people of African origin in the Western Hemisphere" (Temkin 2012, 275-276). Malcolm wanted to expand African Americans' view of their domestic struggle beyond US borders and back to the origins of their predicament in America. Temkin further contends, "The civil rights struggle, as Malcolm saw it, kept blacks under the control of America's domestic jurisdiction; he wanted to transform the black issue in the United States into a geopolitical concern" (Temkin 2012, 276).

Moreover, Malcolm's style of expression drew large crowds because followers and skeptics were mesmerized by his ability to synthesize the national problem of race with what he perceived as moral depravity. As Malcolm moved away from talking solely about religion, his life's trajectory shifted once again, this time into the realm of politics and direct action. And while Elijah Muhammad sought to evade the political sphere, Malcolm appeared to be drawn to it by the hand of providence. Although Malcolm's 
new direction of thought conflicted with Elijah Muhammad, his reverence for his former teacher never waned. In addition, as Malcolm's world view expanded so did his realization that Elijah Muhammad was not the dutiful minister he proclaimed to be before his parishioners. This revelation resulted in their relationship severing over Muhammad's behavior of having children outside of his marriage. Another contributing factor was Muhammad's inability to contain his young protégé. For example, when President John F. Kennedy was assassinated on November 22, 1963, Malcolm was very unsympathetic to Americans grieving the national loss. When asked by a reporter his thoughts on Kennedy's assassination after giving an address at the Manhattan Center, he compared the president's assassination to chickens coming home to roost even though he was advised by Muhammad not to speak on the President's tragic end (Manning 2011). This infraction drew sharp criticism from Muhammad and the entire nation, and Malcolm was silenced for 90 days, which led to his eventual separation from the NOI.

When Malcolm departed from the NOI amid death threats and organizational hypocrisy, he illustrated once more that his search for religious understanding was still in process because he made the decision to embark on a spiritual journey, the Hajj. Louis A. DeCaro, Jr. states, "The Hajj is a profound statement of the [the Hajji's] devotion to God, rejection of sin, and a celebration of the brotherhood of all Moslems [and] it is considered one of the most potent unifying factors in the world of Islam" (Decaro 1996, 203). This voyage for Malcolm would come to signify one of the most pivotal transitions in his life as well as his evolving search for truth.

However, before his departure to Mecca, he made one of his more memorable speeches, entitled "The Ballot or the Bullet," on April 3, 1964. This speech signaled not only his split from the NOI but his growing concern for human rights worldwide. Malcolm presented a series of political scenarios, urging and pleading with African Americans to take part in the electoral process. He also warned audience members of the impending violence that might ensue in communities if the social and economic issues pertinent to their well-being were not addressed. He began this speech by addressing the rumors behind his leaving NOI by stating, "Although I'm still Muslim, I'm not here tonight to discuss my religion, [nor] to change your religion" (X 2003, 51). Malcolm did not waste any time in pushing the issue of his Muslim affiliation to the forefront of his speech so as to move to the heart of the lecture and his unified vision for domestic rights as well as a growing interest in international rights.

In many ways, this speech symbolized the internal struggle Malcolm faced as an NOI member, desiring to be part of the political action, yet restrained under the headship of Elijah Muhammad. In the absence of restrictions from the NOI, Malcolm told a crowded audience that he no longer considered himself an American because America had become a hypocritical nation. He asserted, 'I'm not standing here speaking to you as an American, or a patriot, or a flag saluter, or a flag waver, no, not I" (James 2003, 52). He rejected the idea of an equitable and democratic society due to the suffering and marginalization of so many of its citizens: "I don't see any American dream; I see an American nightmare" (James 2003, 52). Malcolm argued further that there were Americans who were waking up to the reality that they had been left out of the political and social progress of the nation by virtue of their race and position in society. Also, some men and women who were aware of the racially exclusive 
practices by the government also began to realize injustices were occurring beyond the US borders as well.

Malcolm believed participation in the voting process would not only begin to challenge the reality of America's Black and poor citizens but also put pressure on leaders in other nations to treat their citizens more humanely. He continues: "That's why in 1964, it's time now for you and me to become more politically mature and realize what the ballot is for; what we're supposed to get when we cast a ballot; and that if we don't cast a ballot, it's going to end up in a situation where we're going to have to cast a bullet" (James 2003, 55). Malcolm was speaking to the endless number of incidents where racism had prevailed over human decency. This discrimination had been in the form of racial acts of violence and governmental policies enacted to oppress certain races and cultures.

While Malcolm never explicitly advocated violence, this rhetoric does seem to encourage violent action (Terrill 2001). His rhetoric made him a polarizing figure to listeners who only heard the aggression in his words without a clear understanding of the suffering and bloodshed that preceded his lecture and that was occurring even while he spoke. Malcolm responded to those who may have seen him only as someone trying to incite violence: "Well, we're justified in seeking civil rights if it means equality and opportunity, because all we're doing there is trying to collect for our investment; our mothers and fathers invested in sweat and blood" (James 2003, 56). Many elderly individuals in attendance were wary of using violence while some young people interpreted his rhetoric to solely mean killing. Malcolm was fully aware of the skewed interpretations of his speech; hence, he sought to clarify his statement or at the very least to make it more palatable: "Any time you know you're within the law, within your legal rights, within your moral rights, in accord with justice, then die for what you believe in" (James 2003, 58). Beyond a reciprocal reaction to violence, Malcolm also understood the importance of having allies outside of the USA to speak up on behalf of the disenfranchised in America. He redirected the ending of his speech back to the ballot and the power of voting.

Furthermore, he pushed his audience to think about the needs and injustices within the global society by challenging listeners to consider civil rights - a human rights issue. This shift in Malcolm's thinking was yet another change in his philosophical ideology and in his approach to tackling domestic affairs. He points out, "When you expand the civil-rights struggle to the level of human rights, you can then take the case of the black man in this country before the nations of the UN" (James 2003, 58). Once Malcolm separated from the NOI, his worldview broadened; he envisioned indicting the USA but needed the support of voters and global allies to do so.

Moreover, as Malcolm nears the end of his oration, he reiterates his deep abiding religious convictions as a Muslim but also signals to his followers and cynics that the time for political action is now. Malcolm notes, "It's true we're are Muslims and our religion is Islam, but we don't mix our religion with our politics and our economic and our social activities anymore" (James 2003, 60). Malcolm was no longer bound to Muhammad's brand of Islam that disengaged from the civil rights movement; instead, he outlined the responsibility of every citizen to engage in the process of fighting for equality on every level of human existence: "We become involved with anybody, anywhere, any time and in any manner that's designed to eliminate the evils, the political, economic and social evils that are afflicting the people of our community" 
(James 2003, 60). Malcolm's objective was to provoke his audience not only to political action here in the USA but to also consider the struggles of indigenous people all over the world in the fight for human rights. Moshik Temkin argues, "Malcolm saw the oppression of American blacks as one part of a Western phenomenon - colonialism/ imperialism; they happened to be living in the United States because of the historical crime of slavery, and their affinity was not to other US citizens, but rather to a global community" (Temkin 2012, 276). Malcolm's worldview is in part why he left the country 10 days after delivering this speech on a journey to Mecca. This particular religious pilgrimage is encouraged by Orthodox Muslims because of its transformative effect on disciples. While this was not Malcolm's first trip out of the country, the voyage helped to reshape his spiritual outlook from the exclusion of non-whites to the inclusion of all races. Taking part in the hajj brought Malcolm X face to face with Orthodox Islam, a doctrine that was not espoused by the NOI.

Orthodox Islam does not separate its followers based on race. Orthodox Islam is the belief in God (Allah) and the Quran. Religious historian Seyyed Hossein Nasr reasons, "Islam is a return not only to the religion of Abraham, but even to that of Adam, restoring primordial monotheism with identifying it with a single people, as in the case of Judaism, or a single event of human history, as one observes in the prevalent historical view of incarnation in Christian theology" (Nasir 2003, 5). Muslims believe Jesus Christ was a prophet and not the Godhead in the flesh, nor the savior of the world worshipped by Western Christians. Nasr further notes, "The Quran is central to the Islam faith, the verbatim Word of God revealed to the Prophet by the archangel Gabriel and transmitted by him . . . later assembled in its present order under the instruction of the Prophet and written down in several manuscripts" (Nasir 2003, 37). Also, Islamic faith centers on Allah and not a messenger nor the Prophet that is considered the perfect model of human existence.

Moreover, Islam is a religion that encourages unity among its followers. Nasar argues, "Islam's great emphasis on unity . . . integrates a vast segment of humanity with diverse ethnic, linguistic, and cultural backgrounds in its diverse interpretations of its teachings" (Nasir 2003, 37). Orthodox Islam unites many schools of Islamic thought together in search of and discovery of Allah. These truths were eye opening to Malcolm as he traveled through Muslim countries and witnessed people of different races and socioeconomic backgrounds in pursuit of a deeper understanding of Allah. This whole experience was surprising and affirming for Malcolm. He fondly remembers, "Packed in the plane were white, black, brown, red, and yellow people; blue eyes and blond hair, and my kinky red hair - all together, brothers" (Haley 1965, 372)! As he moved further along in his journey, he began to experience the oneness between his brothers as well as the oneness of their God: "Everything about the pilgrimage accented the Oneness of Man under God" (Haley 1965, 380). The interactions with men and women from all over the world contradicted his American experiences and caused him to reevaluate his faith and personal perspective. In the USA, Malcolm faced social, economic, and racial hostility as an African American male, but in the Middle East, he was treated with dignity. This may have been due solely to his religious affiliation with the men and women also taking part in the hajj or to the fact that some global communities were more socially advanced than the USA in 1964. Either way, his acceptance while on the pilgrimage highlighted the extent of the race problem in the USA. And he equated his feelings of liberation to stepping out of a 
prison (Haley 1965). For the first time, Malcolm X experienced the white man not as his enemy but as his friend.

As a result, Malcolm became less judgmental toward white men because of the genuine kindness and hospitality they displayed to him in the Middle East; no longer willing to make blanket statements accusing the white man as the devil. Also, he learned after dining with a Muslim white scholar that wherever there was an issue with color in the Middle East, it was almost always the result of Western influence. After spending a great amount of time eating, talking, traveling, and praying with Muslims, Malcolm began to let go of some skepticism he may have brought with him from America in regard to other races: "The color-blindness of the Muslim world's religious society and the color-blindness of the Muslim world's human society: these two influences had each day been making a greater impact, and an increasing persuasion against my previous way of thinking" (Haley 1965, 389). Malcolm remembers this time in his journey where his core belief system began to change, and he came to loathe the 12 years he spent under the tutelage of Muhammad as well as his American persona. For Malcolm, the hajj caused him to not only reflect on the divisive spiritual training of Muhammad but also on the antagonistic choices he made in carrying out Muhammad's form of Islam. As Malcolm accepted a new all-encompassing way of practicing Islam, he also changed his name to El-Hajj Malik El-Shabazz to reflect this pivotal conversion in his life. In his autobiography, Malcolm stated, "The true Islam has shown me that a blanket indictment of all white people is as wrong as when whites make blanket indictments against blacks" (Haley 2003, 416). His feelings of empathy toward all mankind remained with him once he returned to America and so did his political vigilance to hold America accountable for its refusal to address the race problem that continued to divide its people.

Historians Randy Roberts and Johnny Smith suggest, "Malcolm's beliefs that whites were not inherently evil developed gradually, but this realization did not alter his political ideology . . . At his core, Malcolm X was a Black Nationalist, a soldier at war searching for allies in the black liberation movement" (Roberts and Smith 2016, 247). One can argue that at this juncture in Malcolm's life, he still had a tremendous amount of animosity in his heart against white Americans, due to the history of slavery and other racial atrocities.

In addition, he wanted African Americans to take a more active role in fighting for their rights in this great nation as opposed to waiting for the American government to automatically dispense equality to its marginalized citizens. And while Malcolm X understood the urgency of his rhetoric, he also realized the danger in rallying masses of people to take a stand against worldwide injustices. The NOI was not pleased with Malcolm's new brand of Islam nor his propensity to make known the organization's moral and social contradictions. Therefore, Malcolm became a target of ridicule and hatred. As such, in every NOI mosque, the faithful were obligated to swear fealty to Muhammad and to denounce Malcolm as a heretic (Manning 2011). Muhammad now viewed Malcolm as a traitor to NOI as well as a threat to its doctrine.

Furthermore, Malcolm predicted his haunting death in his autobiography: "In any city, wherever I go, making speeches, holding meetings of my organization or attending to business, black men are watching every move I make, awaiting their chance to kill me" (Haley 1965, 438). On February 21, 1965, Malcolm X was assassinated while giving the opening greetings before his speech was to commence before a large crowd 
at the Audubon Ballroom in New York City. Manning Marable suggests, "Most Malcolmites thought the Nation of Islam was actively conspiring to kill their leader, many also suspected the U.S. government as being behind the murder attempts" (Manning 2011, 429). Whether the Nation or the government orchestrated the death of Malcolm X, his untimely demise left a void in African American culture, and more specifically, in the lives of African American males who revered him for his unapologetic reflection of manhood, intellectual prowess, and spiritual complexity. For instance, when actor Ossie Davis eulogized Malcolm, he made sure to illustrate Malcolm's ability to make African American males feel like men. Davis pointed out, "I knew the man personally, and however much I disagreed with him, I never doubted that Malcolm, even when he was wrong, was always that rarest thing in the world among us Negroes: a true man" (Haley 1965, 527). These sentiments still resonate today with so many African Americans who view Malcolm as an iconic figure who was ahead of his time in regard to how he saw and thought about the world and the manner in which he approached issues of injustice. Also, The Autobiography of Malcolm X has become one of the leading texts in prisons libraries because Malcolm's life demonstrates to inmates the power of knowledge, the pursuit of truth, and the courage to face the unknown.

Moreover, Malcolm's autobiography proves instructional when examining the prison writings of Eldridge Cleaver, George Jackson, Huey Newton, Stanley Tookie Williams, and Dr. Rubin Hurricane Carter. From the perspective of these former inmates, Malcolm epitomized the ideal revolutionary and spiritual philosopher. The narratives explored in subsequent chapters in this study all mirror in some aspect the ideas of identity, activism, and spirituality that Malcolm was still uncovering or realizing at the time of his death. For example, the life of Eldridge Cleaver as chronicled in Soul on Ice illustrates in several ways his connection and admiration for Malcolm's evolution as a man. Cleaver believed, "Malcolm X had a special meaning for black convicts [as] a former prisoner himself . . for this reason he was a symbol of hope, a model for thousands of black convicts who found themselves trapped in the vicious PPP cycle: prison-parole-prison" (Cleaver 1968, 81). Malcolm was a hero for many Black prisoners incarcerated in the 1960s and 1970s because the life he exhibited and words he spoke once he was released from prison compelled others to stand up and be men. Eldridge Cleaver further argues, "When he spoke under the banner of Elijah Muhammad he was irresistible [and] when he spoke under his own banner he was irresistible . . . had he continued to give voice to the mute ambitions in the black man's soul, his message would still have been triumphant: because what was great was not Malcolm X but the truth he uttered" (Cleaver 1968, 82).

In addition to Cleaver's admiration for Malcolm, political prisoner George Jackson also revered him. For Jackson, Malcolm represented everything he was endeavoring to become as a political activist and truth seeker. Although Jackson's life was cut short in prison, his narrative Soledad Brother urged African Americans to remain engaged in the fight for social and political equality. Moreover, he highlights in great detail the disenfranchisement and oppression of the Black prisoner and why he was willing to use any means necessary to fight against state-sanctioned repression. And while the methods Jackson used to contest prison subjugation were radical and merciless, his contribution, or the lack thereof, in examining incarceration and racism in America, continues to point to the militant ideology of Malcolm X. Unlike George Jackson who became politicized in prison and lived out Malcolm's unforgiving rhetoric, Tookie 
Stanley Williams and Rubin "Hurricane" Carter show through their narratives that transformation is possible for inmates.

Both Williams and Carter had similar experiences to Malcolm growing up in homes where the family unit was dysfunctional, thereby, contributing to their adolescent delinquency and eventual incarceration. What is strikingly similar in the narratives Blue Rage, Black Redemption by Williams and The Eye of the Hurricane by Carter to Malcolm's autobiography is that Williams and Carter attest to the transforming power of educating oneself in prison and to adopting a spiritual or religious belief. While Williams and Carter learned to use their fists before they understood the authority that words can carry, they both struggled as did Malcolm X with their position as men in a segregated society. To combat their frustrated feelings of inferiority, they created their own brand of manhood and bravado based on their ability to physically overpower anyone who stood in their way. Williams co-founded the L.A. gang Crips, and Carter became a well known boxer who was unjustly convicted of triple homicide and spent close to 20 years in prison.

However, beyond their questionable past and convictions is the hard work, these men engaged in to move their lives in a new direction of thought once they understood their release from prison was improbable. Stanley Tookie Williams alluded to this difficulty in his narrative: "Everything was working against me: I was an imprisoned black man: condemned to die; co-founder of the infamous and hated Crips; and no one believed I could change; I even had my doubts" (Williams 2004, 271). Even with selfdoubt lingering in his mind, Williams continued to re-educate himself in hope of personal liberation and to serve as an agent of freedom for others. Williams made it a point through his writing and rare opportunities to speak to caution others of the dangers that accompany gang affiliation and life behind bars: "I warn black men and women everywhere: beware of these tombs for the living called prisons" (Williams 2004, 293). The prison narratives by Williams and Carter are more than mere cautionary tales but are literal blueprints for incarcerated men and women who are seeking to change their lives. The Autobiography of Malcolm X sets the precedent for African American prison narratives in the 1960s, and the stories that follow in this study each address in some way the overarching question of incarceration: Is it possible for inmates to change? While Malcolm $\mathrm{X}$ is the personification of a transformed life, the other prisoners highlighted in this project prove that change is possible. In conclusion, individual transformation cannot be evaluated by outward conduct alone but must also take into consideration the emotional and spiritual evolution that can only be judged by one's God.

Open Access This article is licensed under a Creative Commons Attribution 4.0 International License, which permits use, sharing, adaptation, distribution and reproduction in any medium or format, as long as you give appropriate credit to the original author(s) and the source, provide a link to the Creative Commons licence, and indicate if changes were made. The images or other third party material in this article are included in the article's Creative Commons licence, unless indicated otherwise in a credit line to the material. If material is not included in the article's Creative Commons licence and your intended use is not permitted by statutory regulation or exceeds the permitted use, you will need to obtain permission directly from the copyright holder. To view a copy of this licence, visit http://creativecommons.org/licenses/by/4.0/. 


\section{References}

Bassey, M. (1999). Malcolm X: Islam and African American self-consciousness. Dialogue \& Alliance, 13, 50. Cleaver, E. (1968). Soul on ice. Peaslake: Delta Publishing.

Colley, Z. (2014). All America is a Prison: the nation of Islam and the politicization of African American prisoners, 1955-1965. Journal of American Studies, 48, 396-415. https://doi.org/10.1017 /S0021875813001308.

Condit, C., \& Lucaites, J. (1993). Malcolm X and the limits of the rhetoric of revolutionary dissent. Journal of Black Studies, 23, 295 www.jstor.org/stable/2784569.

Curtis, E. (2006). Black Muslim in religion in the nation of Islam, 1960-1975. Chapel Hill: The University of North Carolina Press.

DeCaro, L. (1996). On the side of my people: a religious life of Malcolm. New York: New York University Press.

Epps, A. (1993). The rhetoric of Malcolm X. Harvard Review, 3, 64 http://www.jstor.org/stable/27559632 ?origin=JSTOR-pdf.

Friend, C., \& Glover, L. (2004). Southern manhood: perspectives on masculinity in the Old South. Athens: University of Georgia Press.

Haley, A. (1965). The autobiography of Malcolm X. Random House.

Harper, F. (1971). The influence of Malcolm X on black militancy. Journal of Black Studies, 1, 395. https://doi.org/10.1177/002193477100100401.

Hartwell, A. (2008). Between exodus and Egypt: Malcolm X, Islam and the "natural religion of the oppressed. European Journal of American Culture, 27, 209.

Jacobs, J. (1979). Race relations and the prisoner's subculture. Crime and Justice, 1, 6-27. https://doi. org/10.1086/449057.

LaMothe, R. (2009). Malcolm X's conversion: the interplay of political and religious subjectivities. Pastoral Psychology, 60, 531-536. https://doi.org/10.1007/s11089-009-0256-0.

Manning, M. (2011). Malcolm X: a life of reinvention. Viking Press.

Nasir, S. (2003). Islam: religion, history, and civilization. Harper Collins.

Painter, N. (1993). Malcolm X across genres. American Historical Review, 433. https://doi.org/10.1086/ahr/98.2.432.

Roberts, R., \& Smith, J. (2016). Blood brothers: the fatal friendship between Muhammad Ali and Malcolm X. Basic Books.

Rose, S. (1987). Metaphors and myths of cross-cultural literacy: autobiographical narratives by Maxine Kingston, Richard Rodriguez, and Malcolm X. Ethnic Autobiography, 3, 3. https://doi.org/10.2307/467469.

Saldana-Portillo, M. (1997). Consuming Malcolm X: prophecy and performative masculinity. Novel: 304. https://www.jstor.org/stable/1345757

Temkin, M. (2012). From black revolution to 'radical humanism': Malcolm X between biography and international history. Humanity: An International Journal of Human Rights, Humanitarianism, and Development: 275. https://doi.org/10.1353/hum.2012.0008.

Terrill, R. (2001). Protest, prophecy, and prudence in the rhetoric of Malcolm X. Rhetoric \& Public Affairs, 4, 30-53. https://doi.org/10.1353/rap.2001.0016.

Williams, S. (2004). Blue rage, black redemption. Damali Publishing.

X, M. (2003). The Ballot or the Bullet. Imprisoned intellectuals: America's prisoners write on life, liberation, and rebellion, edited by Joy James. Lanham: Rowman \& Littlefield Publishers.

Publisher's Note Springer Nature remains neutral with regard to jurisdictional claims in published maps and institutional affiliations. 